\title{
Mantle plume activity and melting conditions: Evidence from olivines in picritic-komatiitic rocks from the Emeishan Large Igneous Province, southwestern China
}

\author{
1 Institute of Geology, Chinese Academy of Geological Sciences, Beijing, 100037, China. E-mail: zhangzhaochong@sohu.com \\ 2 China University of Geosciences, Beijing, 100083, China. \\ 3 Institute of Mineral Resources, Chinese Academy of Geological Sciences, Beijing, 100037, China. \\ 4 School of Ocean and Earth Science and Technology, University of Hawaii, Honolulu, HI 96822, USA.
}

\begin{abstract}
Olivine phenocryst compositions and whole-rock chemical compositions are used to identify primitive picrite basalts from the early part of flood basalt successions in the western part of the Emeishan large igneous province (ELIP), southwestern China. The Fo contents of olivine phenocrysts of komatiites with $\mathrm{MgO} \sim 21.79$ wt\% range from $85.2 \%$ to $91.4 \%$. The composition of unerupted parental melts is calculated from the compositions of the most Fo-rich olivine phenocrysts. These melts had 22 wt\% $\mathrm{MgO}$, and originated in mantle with a potential temperature of $\sim 1600^{\circ} \mathrm{C}$ and at about $4.2 \mathrm{GPa}$ pressure, supporting the conclusion that the generation of ELIP can be attributed to melting of a plume head beginning at $\sim 138 \mathrm{~km}$ depth.
\end{abstract}

\section{Introduction}

The $258 \mathrm{Ma}$ Emeishan Province in SW China represents one of the larger Phanerozoic flood basalt events. In recent years it has received considerable international interest because of possible connections between flood volcanism and global mass extinction events (e.g., Wignall, 2001), and a near coincidence of the three major large igneous provinces (LIPs; Emeishan in China, Panjal Traps in India, and Siberian Traps in Russia), which raises important questions concerning global mantle dynamics and the geodynamic setting of the magmatism.

Although the plume model has been widely employed to explain the generation of LIPs, doubts have been raised by some workers about the viability of this model for the ELIP in view of its relatively small exposure $\left(\sim 250,000 \mathrm{~km}^{2}\right.$ in comparison with $1,000,000 \mathrm{~km}^{2}$ typical of other LIPs; e.g., Coffin and Eldholm, 1994) and the relatively few volcanic cycles of the Emeishan lavas (e.g., Thomposon et al., 2001). Anderson (1998) proposed that except for crustal doming immediately preceding eruption or very large volumes of magma ( $106 \mathrm{~km}^{3}$ of basalt) erupted during a very short time interval (order of $1 \mathrm{Myr}$ ), the most convincing argument for a plume would be high magma temperature.

To estimate the magma temperature, it is necessary to place constraints on the primary melt composition. However, few erupted lavas are primary magmas. Highly magnesian volcanic rocks, such as picrites and komatiites, are generally believed to be close to near- primary mantle-derived melts. Thus, we must seek out such relatively rare lavas. Fortunately, though rare, they are found in many LIPs such as the Karoo (Cox et al., 1984), Deccan (Melluso et al., 1995), West Greenland (Clarke, 1970) and East Greenland (Hansen and Nielsen, 1999).

Recently, we discovered two occurrences of picritic-komatiitic lavas (12-25 wt\% MgO, Zhang et al., 2004) in the Lijiang area, Yunnan Province (Figures 1 and 2). Here, we present new results of olivine compositions, and discuss their implications.

\section{Geological setting}

The ELIP is a Late Permian continental flood basalt sequence covering large areas in the provinces of Sichuan, Yunnan, and Guizhou along the eastern margin of the Tibetan Plateau to the western margin of the Yangtze Block in southwestern China (Figure 1). The geo-

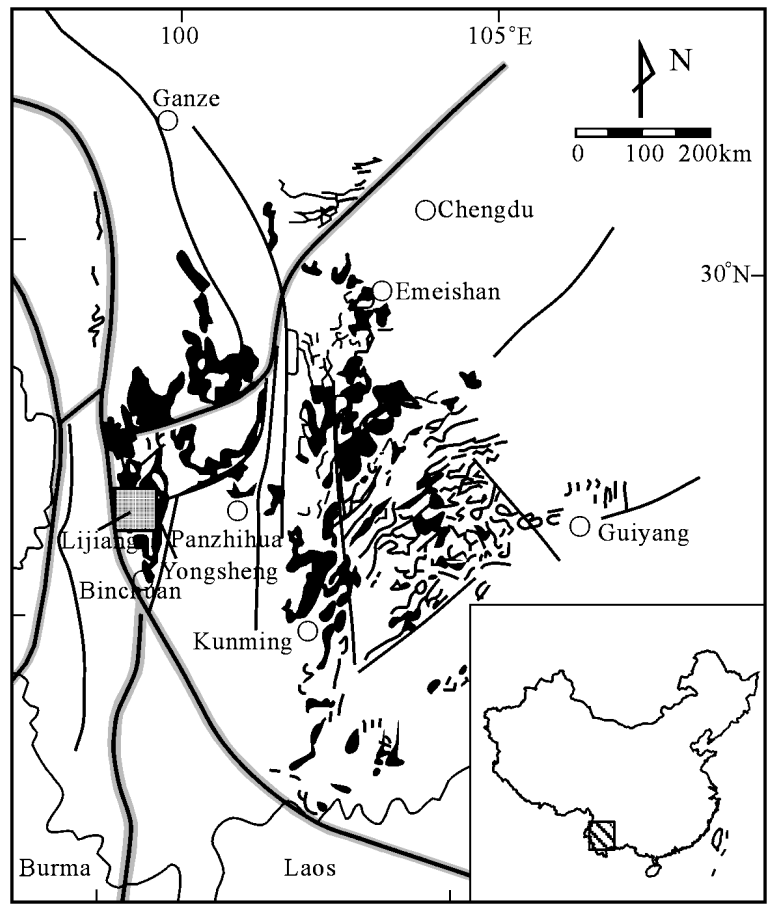

Figure 1 Sketch map showing outcrops of Emeishan flood basalts (black areas; simplified from Chung \& Jahn, 1995). The shaded area marks the location of Figure 2. 

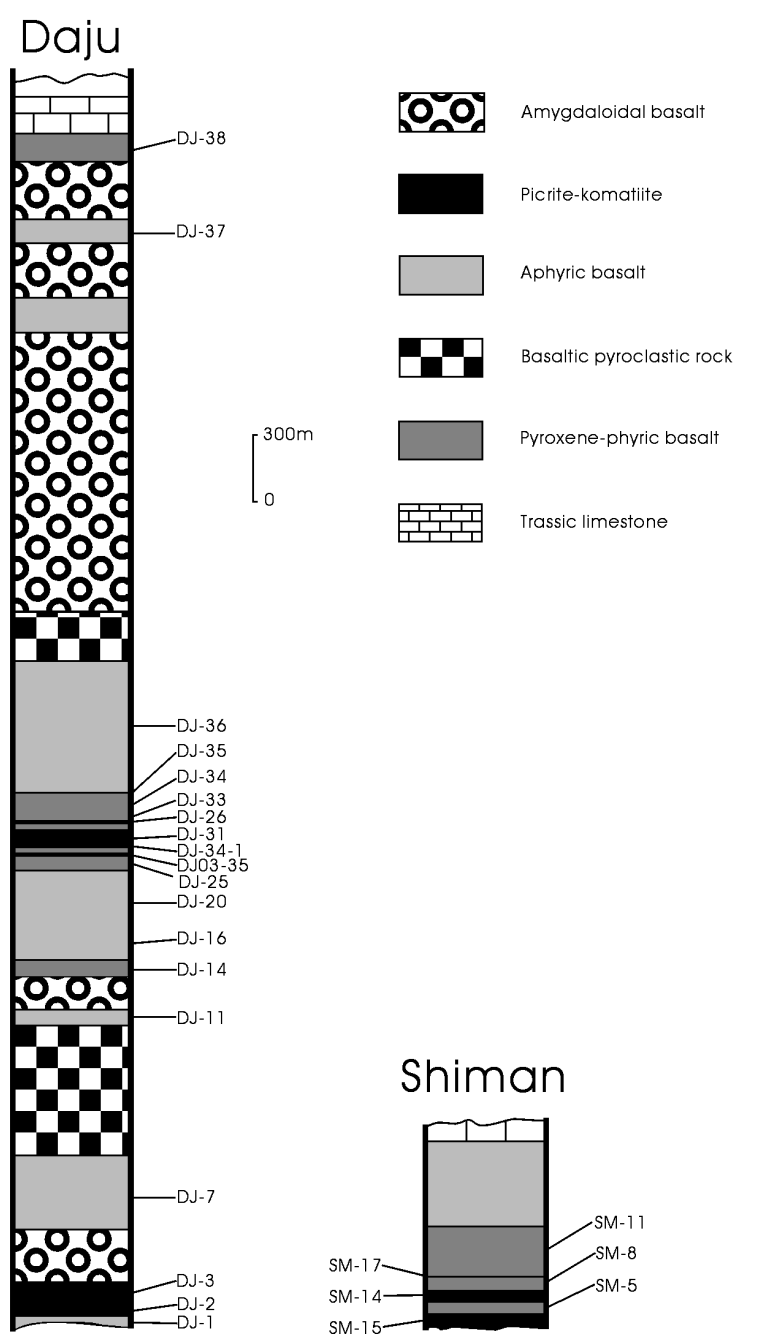

Figure 2 Stratigraphic columns showing the picrites-komatiites and basalts exposed at Daju and Shiman in the Lijiang area. Inferred relative stratigraphic locations for samples that were analyzed for major and trace elements (only a few of which were chosen for microprobe analysis) are shown on the right side of each column. Each shaded part represents an individual lava flow or group of flows.

logical setting and occurrence of the Emeishan basalts have been discussed by several researchers (e.g., Chung and Jahn, 1995; Xu et al., 2001; Lo et al., 2002), and we present only a summary here. Magmatism appears to be associated with Late Permian rifting of the Qiangtang terrane from the Yangtze block. The flood basalts were subsequently uplifted, deformed and segmented by block faulting during the closure of the Tethys Ocean in the Jurassic (Chung et al., 1998). The region was reworked further during the collision between the Indian and Eurasian continents (Leloup et al., 2001).

The main volcanic outcrops cover a rhombic-shaped area of $250,000 \mathrm{~km}^{2}$ and consist of flood basalts together with lesser volumes of picrites and pyroclastic rocks. Thick flows and tuffs of trachytic and rhyolitic composition are abundant in the upper part of the sequence. Although generally much-reduced by erosion, the lava pile averages $705 \mathrm{~m}$ in thickness and locally reaches $5000 \mathrm{~m}$ in the western part of the province. The total eruptive volume is estimated to be between 0.3 and $0.5 \times 10^{6} \mathrm{~km}^{3}$ (Yin et al., 1992; Jin and Shang, 2000); however, given the large amount of erosion, and by comparison with the other continental flood basalts, this amount may represent less than $50 \%$ of the total volume of magma emplaced. The lava successions rest unconformably on the Early Permian Maokou Formation, composed chiefly of marine limestones, and are directly overlain by Late Permian and locally Early Triassic marine strata. A series of layered basic and ultrabasic intrusions, which are associated with large $\mathrm{V}-\mathrm{Ti}-\mathrm{Fe}$ ore deposits and $\mathrm{Cu}-\mathrm{Ni}$-(PGE) ore deposits, are exposed in the central part of the province, apparently underlying the lava pile. These intrusions may represent shallow crustal magma chamber systems that fed the eruptions. Some researchers have determined the age of the ELIP. Lo et al. (2002) concluded from ${ }^{40} \mathrm{Ar}-{ }^{39} \mathrm{Ar}$ dating that the main phase of flood magmatism occurred at 251-253 Ma, whereas Zhou et al. (2002) obtained U-Pb zircon ages of 256-259 Ma for one of the layered intrusions hosting V-TiFe ores.

\section{Field relations and petrography}

Picritic-komatiitic lavas that we discovered recently are located in sections in the southern (Shiman) and northern (Daju) portions of Lijiang county, Yunnan province; the two sections are about $26 \mathrm{~km}$ apart. The geological characteristics of the two picrite-komatiite occurrences are similar. In both sections, the picritic-komatiitic lavas are located in the lower part of the flood basalt pile. In the Shiman section, three picritic-komatiitic flows are intercalated with pyroxene-phyric basaltic lavas, whereas four picritic-komatiitic flows occur in the lower part of the Daju section (Figure 2). It is possible, perhaps likely, that the Shiman section corresponds to the middle part of the much thicker Daju section. Massive aphyric basalts and amygdaloidal basalts are dominant in the middle to upper part of the Daju sequence (Figure 2). In the Shiman section, the lowermost and the uppermost picritic-komatiitic flows are 3 to $5 \mathrm{~m}$ thick, and the middle picritic-komatiitic layer is 15 to $20 \mathrm{~m}$ thick. In the Daju section, the lowermost picritic-komatiitic flow varies from 20 to $50 \mathrm{~m}$ in thickness, whereas the thickness of each of the other three flows is similar to those in the Shiman section. Unlike the central and eastern parts of the ELIP, where plagioclase-phyric basalts are widely exposed, plagioclase-phyric basalts are absent in the Lijiang region.

Most of the picritic-komatiitic rocks are highly porphyritic, and contain abundant forsteritic olivine phenocrysts with minor clinopyroxene and $\mathrm{Cr}$-spinel. Olivine phenocrysts are generally subhedral to rounded and sometimes embayed, ranging from 0.2 to $4 \mathrm{~mm}$ in size; some appear partly resorbed. Strained, kink-banded crystals are absent. However, olivine is generally completely replaced by serpentine in most picritic-komatiitic samples. Only in individual sample SM-15 are unaltered cores preserved (Figure 3). Olivine crystals usually contain scatted inclusions of glass; some enclose small, equant, euhedral to rounded, dark-brown Cr-spinel crystals, usually tens of micrometers across. Some $\mathrm{Cr}$-spinel crystals are also "free" in

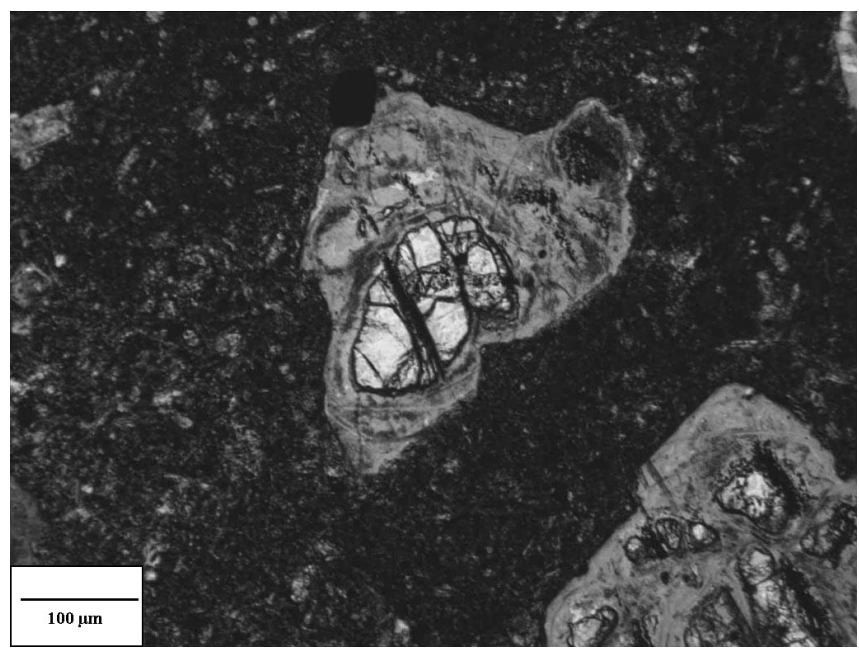

Figure 3 Photomicrograph of komatiite from the Lijiang area. Olivine crystals have rounded or embayed outlines and rims, which are interpreted as a result of resorption. The matrix consists of olivine, ophitically intergrown clinopyroxene and plagioclase and microcrystalline areas of oxide-rich mesostasis. The microphotograph was taken in plane-polarized light. 
the groundmass, which consists of olivine, augite and plagioclase. Quenched olivine groundmass crystals may be tiny and near-equant 'hoppers' but are often elongated, up to $0.5 \mathrm{~mm}$ long and $0.1 \mathrm{~mm}$ wide, and skeletal to highly skeletal, consisting of parallel-set rods and blebs in optical continuity. Groundmass plagioclase occurs as microcrystals rather than the long platy shapes seen in the basalts, and clinopyroxene is anhedrdal. In addition, minor orthopyroxene phenocrysts are observed in some highly magnesian picrites $(\sim 25 \mathrm{wt} \% \mathrm{MgO}$, samples DJ-34-1 and DJ-31, which are strictly komatiites, see the IUGS definition of Le Bas, 2000), which are rarely found in picrites in other LIPs.

The pyroxene-phyric basalts are also porphyritic, with diopside phenocrysts 1-6 mm across; some form glomerocrysts. Phenocrysts account for 5 to $15 \%$ of the volume of the basalts. Groundmass is fine grained with intersertal or intergranular textures, and consists of plagioclase and clinopyroxene with minor iron oxides.

The massive aphyric basalts contain a similar mineral assemblage. Clinopyroxene is the most abundant microphenocryst. The phenocrysts that are present commonly form clots, producing a cumulophyric texture. The pyroxene grains are usually small, generally tens of micrometers across. The groundmass comprises plagioclase laths with interstitial sub-ophitic pale-brown clinopyroxene and minor anhedral magnetite.

\section{Composition of minerals}

The electron microprobe-analyzed results of representative olivine (core), pyroxene and $\mathrm{Cr}$-spinel in the picrites-komatiites and associated basalts are listed in Table 1.

The olivines are denoted by their mg-number, i.e., atomic $100 \mathrm{Mg} /(\mathrm{Mg}+\mathrm{Fe})$. Their mg-numbers span a compositional range from $85.2 \%-91.4 \%$, with most of the analyses in the range from 89-90 (Table 1). The Mg-rich olivines usually contain inclusions of chromite and glass. They are visually indistinguishable from similar olivine crystals with $m g$-number $<90$. The Mg-rich olivines normally constitute about 15 percent of a thin section. All olivines contain small amounts of $\mathrm{CaO}(0.22-0.42 \mathrm{wt} \%), \mathrm{NiO}(0.27-0.44 \mathrm{wt} \%)$, $\mathrm{CoO}(0.01-0.21 \mathrm{wt} \%)$ and $\mathrm{Cr}_{2} \mathrm{O}_{3}(0.03-0.17 \mathrm{wt} \%)$ besides $\mathrm{MgO}$, $\mathrm{FeO}$ and $\mathrm{SiO}_{2}$.

Olivines with $m g$-number $>90$ are a common feature of komatiites (e.g., Arndt et al., 1977; Lesher, 1989), and are also reported from picrites in some LIPs (e.g., Larsen and Pedersen, 2000). They are only rarely reported from mid-ocean ridge basalt (MORB) (Donaldson and Brown, 1977), ocean island basalt (OIB) or continental basalts. On Hawaii, the well-analyzed olivine populations do not exceed mg-number 90.7 (Maaloe and Hansen, 1982; Yang et al., 1994; Baker et al., 1996).

The compositional range in chromite is very small, with mg-number $(\mathrm{Mg} /(\mathrm{Mg}+\mathrm{Fe}))$ 26.0-45.9, Cr-number $(\mathrm{Cr} /(\mathrm{Cr}+\mathrm{Al}))$ 71.5-75.2 and $\mathrm{TiO}_{2}>1 \mathrm{wt} \%$, and high contents of total iron $\left(\mathrm{FeO}_{\mathrm{T}}=22-33 \mathrm{wt} \%\right)$. They are broadly similar to some $\mathrm{Cr}$-spinels from Archaean komatiites, which have high $\mathrm{Fe}$ and $\mathrm{Cr}$ and low Mg and Al (Arndt et al., 1977; Nisbet et al., 1977; Lesher, 1989), but the distinct from those from most abyssal peridotites (Dick and Bullen, 1984) or some continental flood basalts, e.g., West Greenland (Larsen and Pedersen, 2000).

The clinopyroxene is characterized by enrichment in $\mathrm{Ti}$, with $\mathrm{TiO}_{2}$ contents more than $1 \mathrm{wt} \%$, up to $2.85 \%$. The average $\mathrm{TiO}_{2}$ contents of clinopyroxene in the basaltic rocks and picritic-komatiitic rocks are $1.32 \mathrm{wt} \%$ and $1.22 \mathrm{wt} \%$, respectively. Moreover, the $\mathrm{TiO}_{2}$ contents of clinopyroxene increase overall with decreasing $\mathrm{MgO}$ content. In addition, $\mathrm{CaO}$ and $\mathrm{MgO}$ content in clinopyroxene are high, belonging to Ti-bearing augite with $m g$-number $0.72-0.86$. However, the phenocrysts of the pyroxene-phyric basalts are diopside whereas the clinopyroxene in the basalts from other regions of ELIP is augite (Wang et al., 1993).

\section{Discussion and conclusions}

The Mg-rich olivines with $m g$-number $>90$ contain $0.22-0.39$ wt $\%$ $\mathrm{CaO}$ and $0.05-0.17 \mathrm{wt} \% \mathrm{Cr}_{2} \mathrm{O}_{3}$. This shows that the $\mathrm{Mg}$-rich olivines crystallized from melts. They are not xenocrysts of mantle olivines, which have very low contents of $\mathrm{Ca}$ and $\mathrm{Cr}$, less than $0.1 \mathrm{wt} \% \mathrm{CaO}$ and $0.06 \mathrm{wt} \% \mathrm{Cr}_{2} \mathrm{O}_{3}$, respectively (Gurenko et al., 1996; Thompson and Gibson, 2000). Further, the continuous trends through the whole olivine compositional range strongly suggest that the $\mathrm{Mg}$-rich olivine crystals are cognate phenocrysts, and not accidental xenocrysts.

Here, we focus on the most Mg-rich olivines and their implication. It is widely agreed that rocks with picritic characteristics can arise in a variety of ways; for example, as primitive picritic liquids that are little-modified melts of upper-mantle peridotite, by accumulation of early formed olivine from such primary picritic liquids, or by accumulation of olivine from 'normal' basaltic magmas. Under equilibrium conditions, olivine compositions will reflect the composition of the magma from which they crystallize; thus the composition of the olivine phenocrysts in picrites is a valuable clue to estimate the composition of the parental magma. This approach has been used by many workers (e.g. Larsen and Pederson, 2000; Thompson and Gibson, 2000; Simkin et al., 1970; Breddam, 2002; Revillon et al.,1999; Green et al., 2001).

In Figure 4, olivine compositions are plotted as a function of the $\mathrm{MgO}$ contents of the whole rocks. Also shown are curves representing the composition of olivine in equilibrium with liquids with 8,9 , $10,11,12$ and $13 \% \mathrm{FeO}$. These values correspond to $\mathrm{FeO}$ content of likely parental magmas (Figure 4). If the most magnesian olivine from a sample plots on an olivine-liquid equilibrium curve, this indicates that the $\mathrm{MgO}$ content of the whole rock is that of the liquid from which the olivine crystallized; if the olivine plots below the curves, this indicates that the rocks have accumulated olivine (Révillon et al., 1999). The sample SM-15, containing the most Fo-rich olivine phenocrysts, has $21.79 \mathrm{wt} \% \mathrm{MgO}$ and $12.34 \mathrm{wt} \% \mathrm{FeOt}$. Assuming $\mathrm{Fe}^{3+} / \mathrm{Fe}^{2+}=0.15$, the $\mathrm{FeO}$ content of sample SM-15 is calculated to be $\sim 10.73 \mathrm{wt} \%$.

Both cases are represented by the Emeishan picritic-komatiitic rocks. The most magnesian olivine, containing $91.4 \%$ forsterite, plots close to the $10.7 \mathrm{wt} \% \mathrm{FeO}$ curve. From Figure 4, we estimate

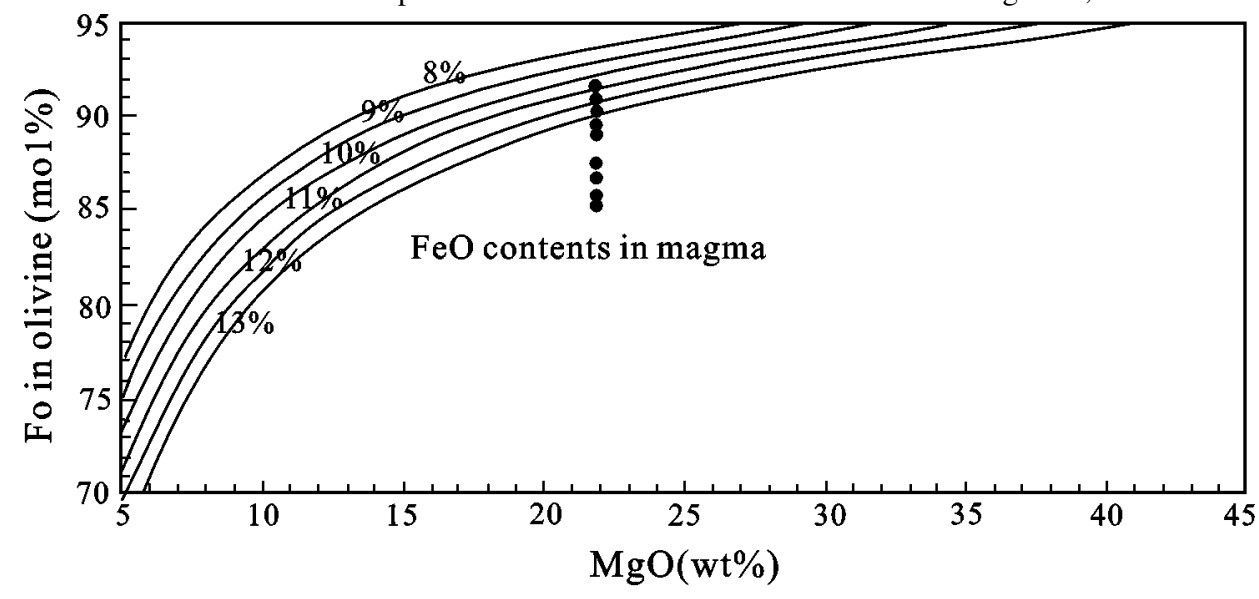

Figure $4 \mathrm{MgO}$ of whole rocks versus Fo contents of olivine in picritic-komatiitic rocks. The curves represent the $\mathrm{MgO}$ content of liquids in chemical equilibrium with olivine for a $\mathrm{K}_{d}$ of $\mathrm{Fe} / \mathrm{Mg}$ between crystal and magma $=0.31$ (Roeder and Emslie, 1970) for magma with $\mathrm{FeO}=8$ to $13 w t \%$. 
Table 1 Representative olivine, pyroxene and Cr-spinel analyses of picrites and associated basalts of the ELIP, SW China (all data in wt\%).

\begin{tabular}{|c|c|c|c|c|c|c|c|c|c|c|c|c|c|c|c|c|c|c|}
\hline Sample & & Minerals & $\mathrm{SiO}_{2}$ & $\mathrm{TiO}_{2}$ & $\mathbf{A l}_{2} \mathbf{O}_{3}$ & FeOt & MnO & MgO & $\mathrm{CaO}$ & $\mathrm{Na}_{2} \mathrm{O}$ & $\mathrm{Cr}_{2} \mathrm{O}$ & ${ }_{3} \mathrm{NiO}$ & $\mathrm{CoO}$ & $\mathrm{V}_{2} \mathrm{O}_{5}$ & Sum & Mg\# & $\mathrm{Cr} \#$ & End member \\
\hline \multirow[t]{15}{*}{ SM-15 } & Ol & Phenocryst & 41.04 & 0.02 & 0.04 & 9.08 & 0.00 & 50.12 & 0.28 & 0.04 & 0.16 & 0.43 & & & 101.35 & 0.908 & & Fo90.8Fa9.2 \\
\hline & $\mathrm{Ol}$ & Phenocryst & 40.57 & 0.05 & 0.04 & 9.40 & 0.10 & 49.62 & 0.30 & 0.04 & 0.13 & 0.44 & & & 100.70 & 0.904 & & Fo90.4Fa9.6 \\
\hline & $\mathrm{Ol}$ & Phenocryst & 39.99 & 0.03 & 0.05 & 14.14 & 0.18 & 45.99 & 0.30 & 0.00 & 0.07 & 0.38 & & & 101.13 & 0.853 & & Fo85.3Fa14.7 \\
\hline & $\mathrm{Ol}$ & Phenocryst & 39.16 & 0.00 & 0.06 & 13.92 & 0.18 & 45.05 & 0.31 & 0.00 & 0.09 & 0.42 & & & 99.19 & 0.852 & & Fo85.2Fa14.8 \\
\hline & $\mathrm{Ol}$ & Phenocryst & 39.97 & & & 8.47 & 0.09 & 50.46 & 0.35 & & 0.06 & 0.41 & 0.07 & & 99.61 & 0.914 & & Fo91.4Fa8. \\
\hline & $\mathrm{Ol}$ & Phenocryst & 40.11 & & & 8.58 & 0.08 & 50.27 & 0.29 & & 0.05 & 0.40 & 0.21 & & 100.00 & 0.913 & & Fo91.3Fa8.7 \\
\hline & $\mathrm{Ol}$ & Phenocryst & 40.04 & & & 8.49 & 0.15 & 50.22 & 0.31 & & 0.09 & 0.43 & 0.01 & & 99.73 & 0.914 & & Fo91.4Fa8.6 \\
\hline & $\mathrm{Ol}$ & Phenocryst & 40.19 & & & 8.75 & 0.11 & 50.02 & 0.29 & & 0.06 & 0.37 & 0.02 & & 99.80 & 0.911 & & Fo91.1Fa8.9 \\
\hline & $\mathrm{Ol}$ & Phenocryst & 40.12 & & & 8.77 & 0.06 & 50.02 & 0.30 & & 0.17 & 0.37 & 0.21 & & 100.01 & 0.910 & & Fo91.0Fa9.0 \\
\hline & $\mathrm{Ol}$ & Phenocryst & 40.18 & & & 9.88 & 0.01 & 48.98 & 0.28 & & 0.01 & 0.36 & 0.13 & & 99.83 & 0.899 & & Fo89.9Fa10.1 \\
\hline & $\mathrm{Ol}$ & Phenocryst & 39.70 & & & 10.07 & 0.28 & 48.77 & 0.42 & & 0.08 & 0.28 & 0.21 & & 99.81 & 0.897 & & Fo89.7Fa10.3 \\
\hline & $\mathrm{Ol}$ & Phenocryst & 39.94 & & & 10.49 & 0.21 & 48.54 & 0.22 & & 0.10 & 0.27 & 0.20 & & 99.98 & 0.893 & & Fo89.3Fa10.7 \\
\hline & & Phenocryst & 39.88 & & & 10.79 & 0.16 & 48.23 & 0.30 & & 0.10 & 0.33 & & & 99.78 & 0.889 & & Fo88.9Fa11.1 \\
\hline & $\mathrm{Ol}$ & Phenocryst & 39.21 & & & 12.21 & 0.24 & 47.40 & 0.33 & & 0.09 & 0.40 & & & 99.88 & 0.875 & & Fo87.5Fa12.5 \\
\hline & $\mathrm{Ol} \mathrm{F}$ & Phenocryst & 39.02 & & & 12.70 & 0.24 & 46.95 & 0.39 & & 0.03 & 0.36 & 0.05 & & 99.75 & 0.869 & & Fo86.9Fa13.1 \\
\hline \multirow[t]{3}{*}{ DJ-31 } & $\mathrm{Ol} \mathrm{F}$ & Phenocryst & 37.78 & 0 & 0.03 & 12.45 & 0.13 & 48.91 & 0.25 & 0 & 0.06 & & & & 99.61 & 0.875 & & Fo87.5Fa12.5 \\
\hline & $\mathrm{Ol} \mathrm{H}$ & Phenocryst & 38.12 & 0 & 0.05 & 12.86 & 0.15 & 47.58 & 0.32 & 0 & 0.05 & & & & 99.13 & 0.868 & & Fo86.8Fa13.2 \\
\hline & & Phenocryst & 37.46 & 0.01 & 0.04 & 13.82 & 0.15 & 47.08 & 0.38 & 0.02 & 0.06 & & & & 99.02 & 0.858 & & Fo85.8Fa14.2 \\
\hline \multirow[t]{3}{*}{ DJ-26 } & $\mathrm{Ol} \mathrm{F}$ & Phenocryst & 37.89 & 0 & 0.03 & 12.09 & 0.14 & 49.00 & 0.27 & 0 & 0.06 & & & & 99.48 & 0.878 & & Fo87.8Fa12.2 \\
\hline & $\mathrm{Ol} \mathrm{H}$ & Phenocryst & 37.97 & 0.01 & 0.04 & 13.3 & 0.14 & 47.39 & 0.29 & 0.03 & 0.06 & & & & 99.23 & 0.863 & & Fo86.3Fa13.7 \\
\hline & $\mathrm{Ol} \mathrm{F}$ & Phenocryst & 37.86 & 0.02 & 0.03 & 14.51 & 0.15 & 46.03 & 0.45 & 0.02 & 0.04 & & & & 99.11 & 0.85 & & Fo85.0Fa 15.0 \\
\hline \multirow[t]{4}{*}{ DJ-34-1 } & $1 \mathrm{Ol} \mathrm{I}$ & Phenocryst & 38.45 & 0.01 & 0.04 & 10.89 & 0.11 & 50.12 & 0.23 & 0.05 & 0.08 & & & & 99.98 & 0.891 & & Fo89.1Fa10.9 \\
\hline & & Phenocryst & 37.71 & 0.02 & 0.08 & 14.22 & 0.14 & 46.25 & 0.41 & 0 & 0.06 & & & & 98.9 & 0.852 & & Fo85.2Fa14.8 \\
\hline & & Phenocryst & 37.43 & 0.01 & 0.04 & 8.99 & 0.09 & 52.46 & 0.22 & 0 & 0.14 & & & & 99.38 & 0.912 & & Fo91.2Fa8.8 \\
\hline & & Phenocryst & 37.92 & 0 & 0.05 & 10.34 & 0.12 & 50.79 & 0.30 & 0 & 0.11 & & & & 99.63 & 0.897 & & Fo89.7Fa10.3 \\
\hline \multirow[t]{7}{*}{ DJ-33 } & $\mathrm{Cpx}$ & Phenocryst & 49.69 & 2.00 & 4.43 & 7.74 & 0.19 & 11.66 & 22.34 & 0.18 & & & & & 98.47 & 0.729 & & Fs $13.5 \mathrm{En} 36.3 \mathrm{Wo}_{0} 0.1$ \\
\hline & $\mathrm{Cpx}$ & Phenocryst & 50.46 & 1.41 & 4.60 & 6.35 & 0.07 & 13.26 & 22.51 & 0.27 & & & & & 99.34 & 0.788 & & Fs 10.8En40.2Wo49.1 \\
\hline & Cpx & Phenocryst & 52.09 & 0.81 & 2.72 & 4.53 & 0.00 & 14.13 & 23.64 & 0.18 & & & & & 98.38 & 0.848 & & Fs7.5En41.9Wo50.5 \\
\hline & $\mathrm{Cpx}$ & Phenocryst & 47.68 & 2.85 & 7.16 & 7.45 & 0.09 & 10.8 & 22.49 & 0.12 & & & & & 98.84 & 0.721 & & Fs13.4En34.7Wo51.9 \\
\hline & Cpx & Phenocryst & 50.32 & 1.17 & 4.10 & 5.77 & 0.11 & 13.74 & 23.19 & 0.06 & & & & & 98.84 & 0.809 & & Fs9.6En40.8Wo49.6 \\
\hline & $\mathrm{Cpx}$ & Phenocryst & 51.65 & 0.94 & 3.65 & 5.07 & 0.11 & 13.98 & 22.78 & 0.20 & & & & & 98.77 & 0.831 & & Fs8.6En42.1Wo49.4 \\
\hline & $\mathrm{Cpx}$ & Phenocryst & 51.68 & 0.86 & 2.80 & 4.28 & 0.03 & 14.55 & 23.54 & 0.12 & & & & & 98.08 & 0.858 & & Fs7.1En42.9Wo50.0 \\
\hline \multirow[t]{6}{*}{ DJ-34 } & $\mathrm{Cpx}$ & Phenocryst & 52.49 & 0.76 & 2.02 & 4.34 & 0.09 & 14.25 & 23.09 & 0.27 & & & & & 97.56 & 0.854 & & Fs7.3n42.8Wo49.9 \\
\hline & Cpx & Phenocryst & 52.87 & 1.17 & 4.89 & 4.35 & 0.00 & 14.43 & 19.93 & 0.27 & & & & & 98.14 & 0.855 & & Fs7.8En46.2Wo46.0 \\
\hline & $\mathrm{Cpx}$ & Phenocryst & 53.07 & 1.03 & 4.12 & 4.10 & 0.00 & 15.42 & 20.42 & 0.16 & & & & & 98.70 & 0.870 & & Fs7.1En47.6Wo45.3 \\
\hline & Cpx & Phenocryst & 52.64 & 1.31 & 5.36 & 4.27 & 0.00 & 14.57 & 20.07 & 0.31 & & & & & 98.86 & 0.859 & & Fs7.6En46.4Wo46.0 \\
\hline & Cpx & Phenocryst & 52.08 & 1.56 & 6.25 & 5.04 & 0.04 & 13.31 & 19.57 & 0.27 & & & & & 98.41 & 0.825 & & Fs9.4En44.0Wo46.6 \\
\hline & $\mathrm{Cpx}$ & Phenocryst & 55.36 & 0.45 & 1.82 & 2.61 & 0.07 & 16.98 & 20.34 & 0.00 & & & & & 98.15 & 0.921 & & Fs4.4En51.3Wo44.2 \\
\hline \multirow[t]{10}{*}{ SM-15 } & Cpx & Quench crystal & 54.18 & 0.69 & 2.90 & 5.04 & 0.13 & 17.49 & 17.86 & 0.42 & & & & & 98.90 & 0.861 & & Fs8.5En52.7Wo38.8 \\
\hline & Cpx & Quench crystal & 53.57 & 1.02 & 3.13 & 8.30 & 0.16 & 16.90 & 16.31 & 0.00 & & & & & 99.52 & 0.784 & & Fs14.5En50.8Wo35.3 \\
\hline & Cpx & Quench crystal & 53.09 & 1.12 & 4.44 & 5.44 & 0.11 & 16.08 & 17.68 & 0.16 & & & & & 98.29 & 0.840 & & Fs9.6En50.5Wo39.9 \\
\hline & Cpx & Quench crystal & 53.16 & 1.06 & 2.94 & 9.01 & 0.32 & 16.83 & 15.73 & 0.09 & & & & & 99.29 & 0.769 & & Fs 15.2En50.7Wo34.1 \\
\hline & Cpx & Quench crystal & 50.03 & 1.20 & 3.41 & 6.93 & 0.18 & 15.898 & 21.50 & 0.23 & 0.24 & 0.10 & 0.18 & 0.226 & 100.12 & 0.803 & & Fs11.0En45.1Wo43.9 \\
\hline & Cpx & Quench crystal & 50.16 & 1.05 & 3.32 & 6.96 & 0.20 & 16.10 & 21.58 & 0.04 & 0.16 & 0.08 & 0.20 & 0.22 & 100.06 & 0.805 & & Fs11.0En45.3Wo43.7 \\
\hline & Cpx & Quench crystal & 50.01 & 1.08 & 3.54 & 7.17 & 0.23 & 15.87 & 21.42 & 0.07 & 0.26 & 0.04 & 0.06 & 0.17 & 99.90 & 0.798 & & Fs11.4En44.9Wo43.7 \\
\hline & Cpx & Quench crystal & 48.06 & 1.68 & 4.38 & 9.12 & 0.28 & 14.70 & 20.66 & 0.44 & 0.41 & 0.02 & 0.09 & 0.10 & 99.93 & 0.742 & & Fs14.7En42.4Wo42.9 \\
\hline & Cpx & Quench crystal & 46.98 & 2.52 & 5.34 & 9.92 & 0.14 & 14.41 & 20.02 & 0.23 & 0.24 & 0.06 & 0.11 & 0.26 & 100.23 & 0.721 & & Fs 16.2En41.9Wo41.9 \\
\hline & Cpx & Quench crystal & 48.83 & 1.59 & 4.52 & 7.17 & 0.15 & 15.65 & 21.27 & 0.14 & 0.28 & & 0.17 & 0.15 & 99.91 & 0.796 & & Fs11.5En44.7Wo43.8 \\
\hline \multirow[t]{2}{*}{ DJ-31 } & Opx & x Phenocryst & 52.56 & 0.00 & 3.52 & 12.45 & 0.20 & 31.15 & 1.10 & 0.00 & 0.21 & & & & 99.59 & & & Fs 17.9En80.0Wo2.0 \\
\hline & Opx & x Phenocryst & 47.56 & 0.00 & 6.97 & 12.09 & 0.17 & 33.92 & 0.22 & 0.00 & 0.11 & & & & 99.42 & & & Fs16.6En83.0Wo0.4 \\
\hline \multirow[t]{2}{*}{ DJ-34-1 } & Opx & x Phenocryst & 49.71 & 0.04 & 9.26 & 8.99 & 0.09 & 31.38 & 1.14 & 0.00 & 0.39 & & & & 99.34 & & & Fs13.5En84.3Wo2.2 \\
\hline & Opx & $\mathrm{x}$ Phenocryst & 50.62 & 0.00 & 6.57 & 10.34 & 0.22 & 30.55 & 2.26 & 0.00 & 0.12 & & & & 99.58 & & & Fs15.3En80.4Wo4.3 \\
\hline \multirow[t]{5}{*}{ SM-15 } & Sp I & Phenocryst & 0.07 & 1.94 & 10.26 & 30.36 & 0.54 & 8.95 & 46.39 & 0.29 & 0.30 & 0.25 & & & 99.36 & \multicolumn{3}{|c|}{$0.345 \quad 0.752$} \\
\hline & $\mathrm{Sp} \mathrm{F}$ & Phenocryst & 0.08 & 1.96 & 10.41 & 31.39 & 0.45 & 8.42 & 46.82 & 0.18 & 0.10 & 0.18 & & & 99.98 & 0.323 & 0.751 & \\
\hline & $\mathrm{Sp} \mathrm{I}$ & Phenocryst & 0.03 & 1.95 & 11.27 & 32.82 & 0.64 & 6.46 & 45.59 & 0.09 & 0.26 & 0.26 & & & 99.37 & 0.260 & 0.731 & \\
\hline & $\mathrm{Sp}$ & Quench crystal & 0.10 & 1.20 & 13.41 & 21.80 & 0.23 & 13.19 & 0.00 & 0.015 & 50.07 & 0.14 & & & 100.15 & 0.410 & 0.715 & \\
\hline & $\mathrm{Sp}$ & Quench crystal & 0.11 & 1.85 & 10.95 & 30.05 & 0.26 & 10.37 & 0.00 & 0.024 & 44.76 & 0.20 & & & 100.01 & 0.459 & 0.733 & \\
\hline
\end{tabular}


that the $\mathrm{MgO}$ content of the parental liquid was $\sim 22 \mathrm{wt} \%$. Therefore, sample SM-15, with $\mathrm{MgO}=21.79$ wt\% (Zhang et al., 2004), can represent the composition of parental magma. Some komatiitic rocks with $\mathrm{MgO}$ contents 25 wt\% (DJ-31 and DJ-34-1) formed through the accumulation of olivine that had crystallized from less magnesian liquids, which is consistent with the fact that they contain some orthopyroxene, which crystallizes relatively late in evolved magmas.

Highly magnesian volcanic rocks, particularly picritic-komatiitic rocks, have been used to estimate mantle melting conditions and mantle compositions because their composition may be close to near-primary mantle-derived melts.

Determining the potential temperature (Tp) can be approached in three main ways: comparison of natural melt compositions with melts produced experimentally from a suitable source under known, realistic, pressure and temperature conditions (e.g., Albarede, 1992); mathematical inversion of erupted melt compositions assuming fractional melting in a polybaric melt column using an assumed mantle source and an experimentally determined pressure- and temperaturedependent sub-solidus assemblage (McKenzie and O'Nions, 1991); and comparison of natural melt compositions and forward melt modelling of idealized mantle sources (e.g., Fram and Lesher, 1993; Thirlwall et al., 1994).

We use the first technique to estimate the potential temperature (Tp) and magma segragation pressure. As sample SM-15 represents a primary magma composition, a hypothetical "eruptive temperature" at $1 \mathrm{~atm}$ and $1450^{\circ} \mathrm{C}$ for such a melt, can be obtained based on the equation of Nisbet et al. (1993) $\mathrm{T}\left({ }^{\circ} \mathrm{C}\right)=17.86 \quad \mathrm{X}$ $\mathrm{MgO}(\%)+1061^{\circ} \mathrm{C}$. A melt fraction for the $22 \% \mathrm{MgO}$ komatiite is estimated to be, $X=31.67 \%$ on the basis of experimental evidence (Takahashi et al., 1993; Herzberg and Zhang,1996; Falloon et al., 1999). Plotting this point on a pressure-temperature diagram for peritotite KLB-1 mantle (Takahashi et al., 1993; Herzberg and Zhang, 1996), the value of Tp of KLB-1 mantle required to generate this melt fraction by anhydrous decompression can be estimated by the method of McKenzie and Bickle (1988). The result is $\mathrm{T}=1600^{\circ} \mathrm{C}$ with dry melting beginning at $4.2 \mathrm{GPa}$ (Figure 5). In other words, the primary magma was generated at $138 \mathrm{~km}$ depth. Using the same method, Thompson and Gibson (2000) calculated Hawaiian plume $\mathrm{Tp}$, to be $1525^{\circ} \mathrm{C}$. Arndt (2000) argued that such a calculation could cause an error of about $100^{\circ} \mathrm{C}$ (higher or lower), because it is affected by some uncertain factors, e.g., pressure, oxygen fugacity,

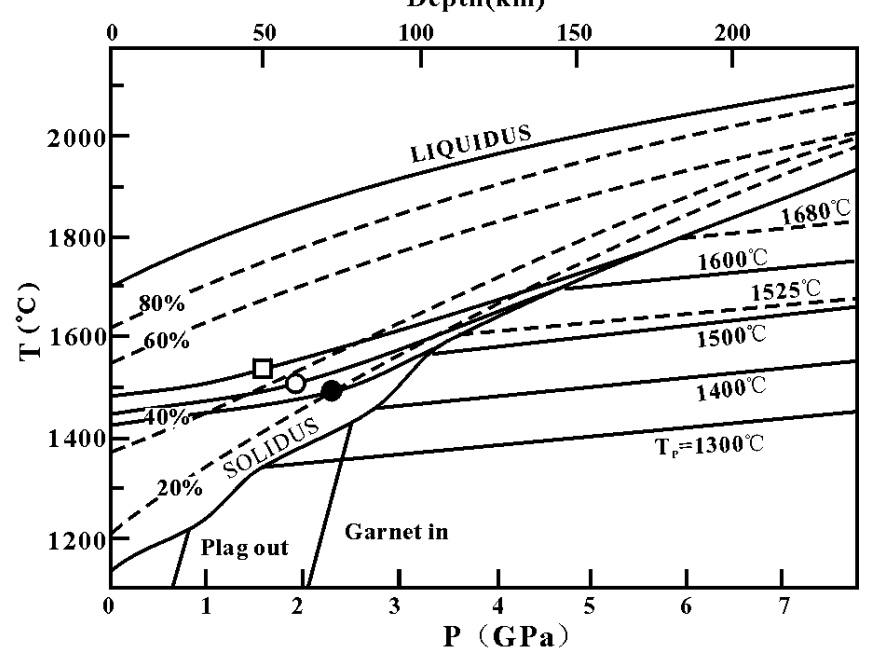

Figure 5 Temperature-pressure diagram showing the melting of anhydrous mantle peridotite KLB-1 (after Thompson and Gibson, 2000). The vertical coordinate is the temperature at 1 atm. Dotted line represents melt fraction. The adiabats for representative mantle potential temperatures are marked as solid lines. Estimates for picrites from Horingbaai in Namibia (square) and Mauna Loa (solid circle) in Hawaii are shown for comparison. Open circle is for Emeishan komatiite SM-15. water, etc. It should be noted that hydrous minerals such as amphibole and biotite are absent in the interstices of coarsely holocrystalline komatiite. In this respect, the samples contrast with the meimechites of the Siberian LIP, which have $25 \mathrm{wt} \% \mathrm{MgO}$ and Fo93 olivines, but with interstitial hydroxyl-biotite (Arndt et al., 1997). It therefore can be inferred that water is absent in the primary magma or there is little water in the magma, although a small water content would change the calculated temperature. Thus, the error should be lower than $100^{\circ} \mathrm{C}$.

The mantle potential temperature that the $\mathrm{Mg}$-rich melt implies $\left(\sim 1600^{\circ} \mathrm{C}\right)$ is about $75^{\circ} \mathrm{C}$ more than the present-day values for Hawaii and Iceland plumes (White and McKenzie, 1995; Watson and McKenzie, 1991; Ribe and Christensen, 1999; Shen et al., 1998), and an increase of $\sim 250-320^{\circ} \mathrm{C}$ above the global normal potential asthenospheric mantle temperature of $1280-1350^{\circ} \mathrm{C}$ (McKenzie and Bickle, 1988). This suggests that the generation of the primary magma was related to a mantle plume, because normal mantle does not reach such high temperature. A high magmatic temperature is also supported by the high $\mathrm{Cr}$ contents of the spinel (cf. Larsen and Pederson, 2000). Hence, we infer that the primary magma was generated by decompression melting of a mantle plume head impinging on the base of the lithosphere at about $138 \mathrm{~km}$ depth.

\section{Acknowledgements}

This material is based upon work supported by the National Science Foundation of China (Nos. 40273020 and 40172026), National Key Fundamental Research Project (No. G1999043205) and Programme of Excellent Young Scientist Project of the Ministry of Land and Resources. We are grateful to the Yunnan Bureau of Geology and Mineral Resources for support of this project during our stay in the field. We also appreciate the support of and many helpful discussions with Drs. Fan Weimin, Xu Yigang, Deng Hailin, Xu Jifeng, and Wang Yuejun. Dr. Yaoling Niu helped us finish the microprobe analysis at Cardiff University, for which we are grateful.

\section{References}

Albarede, F., 1992. How deep do common basaltic magmas form and differentiate? J. Geophys. Res., 97(B), 10997-11009.

Anderson, D.L., 1998. The EDGES of the mantle, in M.E. Gurnis, E.K. Wysession, and B.A. Buffett (eds): The Core-Mantle Boundary Region, edited by 255-271, AGU, Washington, D. C.

Arndt, N. T., Naldrett, A. J. and Pyke, D. R., 1977. Komatiitic and iron-rich tholeiitic lavas of Munro Township, northeast Ontario. J. Petrol., 18, 319369.

Arndt , N. T., Kerr, A. C. and Tarney, J., 1997. Dynamic melting in plume heads: the formation of Gorgona komatiites and basalts. Earth Sci. Planet. Lett., 146, 289-301.

Arndt, N. T., 2000. Hot heads and cold tails. Nature, 407, 458-461.

Baker, M. B., Alves, S. and Stolper, E., 1996. Petrography and petrology of the Hawaii Scientific Drilling Project lavas: inferences from olivine phenocryst abundances and compositions. J. Geophys. Res., 101 (B), 1171511727.

Breddam, K., 2002. Kistufell: Primitive melt from the Iceland mantle plume. J. Petrology, 43, 345-373.

Chung, S. L. and Jahn, B. M., 1995. Plume-lithosphere interaction in generation of the Emeishan flood basalts at the Permian-Triassic boundary. Geology, 23, 889-892.

Chung, S. L. Jahn, B. M., Wu, G., Lo, C. H., and Cong, B., 1998. The Emeishan flood basalt in SW China; a mantle plume initiation model and its connection with continental breakup and mass extinction at the PermianTriassic boundary. In: Flower, M.F.J., Chung, S.-L., Lo, C.-H. and Lee, T.-Y. eds., Mantle Dynamics and Plate Interactions in East Asia. AGU Geodynamics Series, 27, 47-58

Clarke, D. B., 1970. Tertiary basalts of the Baffin Bay: possible primary magma from the mantle. Contrib. Mineral. Petrol., 25, 203-224.

Coffin, M. F. and Eldholm, O., 1994. Large igneous provinces: crustal structure, dimension, and external consequences. Rev. Geophys., 32, 1-36. 
Dick, H.J.B. and Bullen, T., 1984. Chromian spinel as a petrogenetic indicator in abyssal and alpine-type peridotites and spatially associated lavas. Contrib. Mineral. Petrol., 86, 54-76.

Donaldson, C. H. and Brown, R. W., 1977. Refractory megacrysts and magnesium-rich melt inclusions within spinel in oceanic tholeiites; indicators of magma mixing and parental magma composition. Earth Planet. Sci. Lett., 37, 81-89.

Falloon, T. J., Green, D. H., Danyushevsky, L. V. and Faul, U. H., 1999. Peridotite melting at 1.0 and $1.5 \mathrm{GPa}$ : an experimental evaluation of techniques using diamond aggregates and mineral mixes for determination of near-solidus melts. J. Petrol., 40, 1343-1375.

Fram, M. S. and Lesher, C. E., 1993. Geochemical constraints on mantle melting during creation of the North Atlantic basin. Nature, 363, 712 715 .

Green, D. H., Falloon, T., Eggins, S. M; Yaxley, G.. M., 2001. Primary magmas and mantle temperatures. European Journal of Mineralogy, 13, 37451 .

Gurenko, A. A., Hansteen, T. H. and Schmincke, H. U., 1996. Evolution of parental magmas of Miocene shield basalts of Gran Canaria (Canary Island, Greenlands): constraints from crystal, melt and fluid inclusions in minerals. Contrib. Mineral. Petrol., 89, 422-435.

Hansen, H. and Niesen, T. F. D., 1999. Crustal contamination in Paleogene East Greenland flood basalts: plumbing system evolution during continental rifting. Chem. Geol., 157, 89-118.

Herzberg, C. and Zhang, J., 1996. Melting experiments on anhydrous peridotite KLB-1: compositions of magmas in the upper mantle and transition zone. J. Geophys. Res., 101, 8271-8295.

Jin Y., and Shang J., 2000. The Permian of China and its interregional correlation. In Yin, H. ed., Permian-Triassic Evolution of Tethys and Western Circum-Pacific. Dev. Palaeo. Strat. 18: 71-98.

Kerr A C, 1994. Lithospheric thinning during the evolution of continental large igneous provinces: A case study from the North Atlantic Tertiary province. Geology, 22, 1027-1030.

Larsen, L.M and Pedersen, A. K., 2000. Processes in high-Mg, high-T magmas: Evidence from olivine, chromite and glass in Palaeogene picrites from West Greenland. J. Petrol., 41, 1071-1098.

Le Bas, M. J., 2000. IUGS reclassification of the high-Mg and picritic volcanic rocks. J. Petrol., 41, 1467-1470.

Leloup, P. H., Arnaud, N., Lacassin, R., Kienast, J. R., Harrison, T. M., , Trinh, P. T., Replumaz, A. and Tapponnier P., 2001. New constraints on the structure, thermochronology and timing of the Ailao Shan-Red River shear zone. J. Geophys. Res., 106, 6683-6732.

Lesher, C. M., 1989. Komatiite-associated nickel sulfide deposits. In Whitney J. A and Naldrett A. J. eds., Ore Deposition Associated with Magmas. Reviews in Economic Geology, 4, 45-101.

Lo, C., Chung, S., Lee, T. and Wu, G., 2002. Age of the Emeishan flood magmatism and relations to Permian-Triassic boundary events. Earth Planet Sci. Lett., 198, 449-458.

Maaloe, S. and Hansen, B., 1982. Olivine phenocrysts of Hawaiian olivine tholeiite and oceanite. Contrib. Mineral. Petrol., 81, 203-211.

McKenzie, D. and Bickle, M. J., 1988. The volume and composition of melt generated by extension of the lithosphere. J. Petrol., 29, 625-675.

McKenzie, D. and OíNions K., 1991. Partial melt distributions from inversion of rare earth element concentrations. J. Petrol., 32, 1021-1091.

Melluso, L., Beccaluva, L., Brotzu, P., Gregnanin, A. K., Morbidelli, L. and Traversa, 1995. Constraints on the mantle source of the Deccan Traps from the petrology and geochemistry of the basalts of Gujarat State (western India). J. Petrol., 36, 1393-1432.

Nisbet, E. G., Bickle, M. J. and Martin, A., 1977. The mafic and ultramafic lavas of the Belingwe greenstone belt, Rhodesia. J. Petrol., 18, 521-566.

Nisbet, E. G., Cheadle, M. J., Arndt, N. T. and Bickle, M. J., 1993. Constraining the potential temperature of the Archaean mantle: a review of the evidence from komatiites. Lithos, 30, 291-307.

Révillon, S., Arndt, N. T. and Hallot, E., 1999. Petrogenesis of picrites from the Caribbean Plateau and the North Atlantic magmatic province. Lithos, $49,1-21$

Ribe, N. M. and Christensen, U. R., 1999. The dynamical origin of Hawaiian volcanism. Earth Planet. Sci. Lett., 171:517-531.

Roeder, P. L. and Emslie, R. F., 1970. Olivine-liquid equilibrium. Contrib. Mineral Petrol., 29, 275-289.

Shen, Y., Solomon, S. C. and Bjarnason, 1998. Seismic evidence for a lowermantle origin of the Icelandic plume . Nature, 395, 62-65.

Simpkin, T. and Smith, J. V., 1970. Minor elements distribution in olivine. J. Geol., 78, 304-325.

Takahashi, E., Shimazaki, T., Tsuzaki, Y. and Yoshida, H., 1993. Melting study of a peridotite KLB-1 to $6.5 \mathrm{GPa}$ and the origin of basaltic magmas. Philos. Trans. R. Soc. Lond., A 342, 105-120.
Thirlwall, M. F., Upton, B. G. J. and Jenkins, C., 1994. Interaction between continental lithosphere and the Iceland Plume- $\mathrm{Sr}-\mathrm{Nd}-\mathrm{Pb}$ isotope geochemistry of Tertiary basalts, NE Greenland. J. Petrol., 35, 839-879.

Thompson, G., Ali, J., Song, X. and Jolley, D.W., 2001. Emeishan basalts, SW China: reappraisal of the formationís type area stratigraphy and a discussion of the significance as a large igneous province. J. Geol. Soc. London, 2001, 158, 593-599.

Thompson, N. R. N. and Gibson, S. A. 2000. Transient high temperatures in mantle plume heads inferred from magnesian olivines in Phanerozoic picrites. Nature, 2000, 407, 502-506.

Wang, Y, Li J, Zhou, R, Tong, C.H. and Xiong X. H., 1993. Principal and Applications of Trace Element Geochemistry of Magma RocksDiscussion on the Petrogenesis of the Emeishan Basalts. Chengdu Unioversity of Science and Technology (in Chinese).

Watson, S. and McKenzie, D. P., 1991. Melt generation by plumes: a study of Hawaiian volcanism. J. Petrol., 32, 501-537.

White, R. S. and McKenzie, D. P., 1995. Mantle plume and flood basalts. J. Geophys. Res., 100, 17543-17686.

Wignall, P.B., 2001. Large igneous provinces and mass extinctions. Earth Science Reviews 53, 1-33.

Xu, Y., Chung, S., Jahn, B. and Wu, G., 2001. Petrologic and geochemical constraints on the petrogenesis of Permian-Triassic Emeishan flood basalts in southern China. Lithos, 58, 145-168.

Yang, H. J., Frey, F., Garcia, M. O. and Clague, D. A., 1994. Submarine lavas from Mauna Kea volcano, Hawaii: implications for Hawaiian shield stage processes. J. Geophy. Res., 99 (B), 15577-15594.

Yin, H. H., Huang, S., Zhang, K., Hansen, H. J., Yang, F. Q., Ding M. and Bie X., 1992. The effects of volcanism on the Permo-Triassic mass extinction in South China. In Sweet, W.C. ed., Permo-Triassic Events in Eastern Tethys. Cambridge University Press, Cambridge, 146-157.

Zhang, Z. C., Wang, F. S. and Mahoney, John J., 2004. Petrology, Mineralogy, and Geochemistry of the Emeishan Continental Flood Basalts, Southwestern China: evidence for activity of mantle plume. Acta Geologica Sinica, 78, 40-51.

Zhou, M. F., Malpas J. and Song, X. Y., 2002. A temporal link between the Emeishan large igneous province (SW China) and the end-Guadalupian mass extinction. Earth Planet. Sci. Lett., 196, 113-122.

\section{Zhaochong Zhang, graduated from} the Department of Geology, Peking University, received his PhD degree at the Graduate School, Chinese Academy of Geological Sciences (CAGS) in 1995, is a research Professor at the China University of geosciences, Beijing. His interest is mainly on igneous petrology and its related ore deposits.

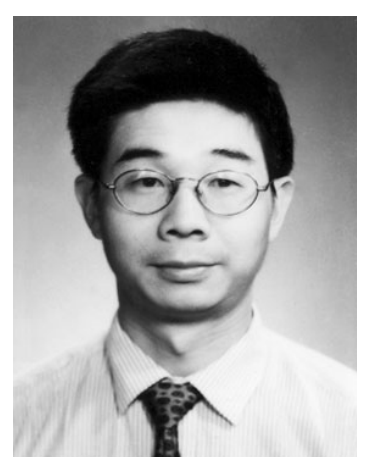

